\title{
KONSUMSI MAKANAN CEPAT SAJI PADA REMAJA DI SURABAYA
}

\author{
Astrida Budiarti ${ }^{1}$ \\ Sekolah Tinggi llmu Kesehatan Hang Tuah Surabaya \\ Corresponding author E-mail : as3da ns@yahoo.com \\ Margaretha Patri Pal Utami ${ }^{2}$ \\ Sekolah Tinggi llmu Kesehatan Hang Tuah Surabaya
}

\begin{abstract}
ABSTRAK
Tingkat kesibukan masyarakat membuat masyarakat menyukai sesuatu yang praktis, termasuk dalam pemilihan makanan. Makanan cepat saji sangat mudah di jumpai sehingga banyak orang menyukainya. Disisi lain, kandungan gizi makanan cepat saji yang tidak seimbang akan menimbulkan masalah gizi, dan merupakan faktor risiko berat badan lebih atau obesitas serta berbagai penyakit degeneratif. Perilaku ini tentunya sangat berbahaya jika dimiliki oleh remaja, karena dampak negatifnya akan didapatkan sekarang maupun jangka panjang yang akan menurunkan kualitas kesehatan bangsa. Tujuan dari penelitian ini adalah memberikan gambaran konsumsi makanan cepat saji dan kejadian obesitas pada remaja di Surabaya. Metode penelitian ini menggunakan studi Analisis Observasional pendekatan Cross Sectional. Populasi adalah remaja SMP di Surabaya dengan jumlah sampel sebanyak 166 orang. Cara pemilihan sampel dengan probability sampling yaitusecara cluster sampling. Alat pengambilan data adalah menggunakan kuesioner JFIM (Junk Food Intake Measure). Hasil penelitian menunjukkan bahwa mayoritas remaja sebesar $84,3 \%$ mengkonsumsi makanan cepat saji dengan frekuensi yang tinggiserta terdapat hubungan antara konsumsi makanan cepat saji dengan kejadian gizi lebih ( $p$ $=0,037$ ). Perlu kerjasama yang baik antara pihak sekolah dan Puskesmas dalam mengedukasi remaja tentang bahaya mengkonsumsi junkfood dalam frekuensi yang tinggi. Selain itu penting juga untuk memberikan edukasi kepada orang tua agar menyediakan makanan yang sehat dirumah. Peran sekolah juga sangat penting dalam menyediakan kantin sehat, sehingga gerakan masyarakat sehat yang dicanangkan pemerintah bisa terdukung dengan baik.
\end{abstract}

Kata Kunci : Junk food, Remaja, Nutrisi

\section{ABSTRACT}

The level of daily activity makes people like something practical, including selection of food. Fast food is very easy to find, so many people like it. The unbalanced nutritional content of fast food will cause nutritional problems, and is a risk factor for overweight or obesity and various degenerative diseases. This behavior is certainly very dangerous for teenagers, because the negative impact will be obtained now and in the long term which will reduce the quality of the nation's health. The purpose of this study was to provide an overview of fast food consumption and the incidence of obesity in adolescents in Surabaya. This research method uses an observational analysis study with cross sectional approach. The population is junior high school in Surabaya with a total sample of 166 people. The method of selecting samples with probability sampling is cluster sampling. The data collection tool was using the JFIM (Junk Food Intake Measure) questionnaire. The results showed that the majority of adolescents, $84.3 \%$, consumed fast food with a high frequency and there was a relationship between consumption of fast food and the incidence of overnutrition ( $p=0.037)$. It needs good cooperation between the school and the Puskesmas in educating adolescents about the dangers of consuming junk food in a high frequency. In addition, it is also important to provide education to parents in order to provide healthy food at home. The role of schools is also very important in providing healthy canteens, so that the healthy community movement launched by the government can be well supported.

Keywords : Junk food, Adolescents, Nutrition

\section{PENDAHULUAN}

Konsumsi Junk food menjadi fenomena yang kini dialami bangsa ini. Terdapatnya fenomena orang tua merayakan ulang tahun anaknya saat ini di gerai-gerai makanan cepat saji yang terdapat di pusat keramaian 
kota karena tempat dan gengsi dari orangtua. Kantin sekolah saat ini juga menyediakan makanan cepat saji seperti mie instan, minuman bersoda (soft drink), kentang goreng dan sebagainya.

Remaja adalah perubahan dari masa anak-anak menjadi dewasa. Perubahan tersebut meliputi perubahan hormon, perubahan fisik, perubahan psikologi dan sosial (Manuaba, 2007). Di dunia diperkirakan kelompok remaja berjumlah 1,2 milyar atau $18 \%$ dari jumlah penduduk dunia. Makanan yang disenangi remaja adalah makanan cepat saji (Junk food). Junk food memiliki kandungan gizi yang tidak seimbang yaitu mengandung kalori tinggi, lemak tinggi, rendah serat dan gula tinggi (Damayanti, 2008). Makanan yang tergolong Junk food antara lain kentang goreng, hamburger, soft drink, pizza, hotdog, donat dan lain-lain (Padmiari, 2002).

Hasil laporan Riset Kesehatan Dasar JATIM (Riskesdas JATIM) 2018 diketahui bahwa $36,2 \%$ remaja di Jawa Timur mengalami obesitas dan overweight di umur 18 tahun. Menurut penelitian Shinta (2011), responden dengan kategori status gizi lebih yaitu sebanyak $46,7 \%$ mempunyai frekuensi konsumsi Junk food 1-2 kali dalam seminggu. Sesuai data dari beberapa sektor Industri di Indonesia di tahun 2008 pertumbuhan industri makanan mencapai $19,4 \%$ pertahunnya. Hal ini membuktikan bahwa konsumen makanan Junk food semakin meningkat dan semakin digemari banyak kalangan. Dari data survey tahun 2007 didapatkan hasil bahwa $28 \%$ masyarakat Indonesia mengonsumsi Junk food minimal setiap satu minggu sekali, sebanyak $33 \%$ lebih sering mengkonsumsi Junk food pada siang hari. Dari hasil ini, Indonesia termasuk ke dalam negara ke 10 yang paling banyak mengkonsumsi makan makananan Junk food. (Damapoliet al, 2013).

Mengkonsumsi Junk food dapat menyebabkan gangguan kesehatan yang bervariasi yaitu seperti infeksi, keracunan makanan, kanker, penyakit gigi, obesitas, penyakit kardiovaskuler, gangguan metabolik dan gangguan psikologi (Maria Saroja, 2018).Makanan cepat saji atau yang lebih dikenal Junk food mengandung asam jenuh yang tinggi, omega 6 asam lemak, asupan omega 3 lemak yang kurang dan garam serta gula yang berlebihan, sehingga makanan tersebut dapat merusak jantung, ginjal, dan obesitas. Namun semakin jelas terlihat bahwa Junk food juga merusak sisitem kekebalan tubuh (Gopal, 2012). Sedangkan pada remaja putri yang terlalu banyak mengkonsumsi Junk food mengakibatkan status gizi yang tidak baik atau overweight akan memproduksi hormon esterogen lebih banyak dibanding remaja putri lain, sehingga masalah ini memerlukan perhatian penting (Roshental, 2009). Konsumsi beragam dan bergizi seimbang mempengaruhi perkembangan organ reproduksi remaja. berdasarkan penelitian yang dilakukan oleh Susanti (2012), dapat disimpulkan bahwa asupan konsumsi lemak yang berlebih merupakan faktor resiko terjadinya status gizi tidak normal (obesitas,gemuk,overweight). Asupan lemak berlebih ini dipengaruhi oleh keterbatasan pengetahuan mengenai asupan makanan yang dikonsumsi, sehingga remaja tertarik untuk mengkonsumsi makanan olahan, terutama makanan yang kaya akan lemak (Arisman, 2009). Remaja yang memiliki berat badan yang lebih tinggi dibandingkan remaja pada umumnya serta memiliki status gizi lebih atau obesitas berpotensi mengalamimenarchedini,ganguan

metabolik, ganguankardiovaskulerdan penyakit gigi nantinya (Maria Saroja, 2018).

Pelayanan Kesehatan Peduli Remaja (PKPR) yang disusun oleh Kementrian Kesehatan pada tahun 2003, pedoman berisikan materi kesehatan reproduksi, tumbuh kembang gizi, Infeksi Menular Seksual (IMS) dan perilaku hidup sehat. Kota Surabaya juga telah mengembangkan Posyandu Remaja, suatu pos pelayanan yang memberikan pelayanan kesehatan, terutama promotif dan preventif (Isfandri et al, 2015). Berdasarkan latar belakang diatas, maka dilakukan penelitian ini untuk menganalisis hubungan antara konsumsi 
makanan cepat saji dengan kejadian obesitas pada siswa dan siswi di SMPN 27 Surabaya.

\section{METODE PENELITIAN}

Dalam penelitian ini menggunakan studi Analisis Observasional pendekatan Cross Sectional. Penelitian dilaksanakan pada bulan Oktober 2020. Populasi adalah semua murid kelas 7, 8 dan 9 SMP di Surabaya dengan jumlah pupolasi 350 siswa. Sampel yang diambil adalah yang memenuhi kriteria inklusi dan eksklusi sebanyak 166 siswa dengan metode probability random sampling dengan cluster sampling. Pengambilan data adalah meliputi data demografi dan data konsumsi junk food dengan menggunakan instrumen JFIM(Junk Food Intake Measure). Beberapa parameter junk food yang diukur menurut JFIM ada lima yaitu : kentang goreng, Camilan asin (MSG), Biskuit manis, Permen/coklat, dan Es krim, diamana setiap point makanan memiliki nilai mulai dari tidak pernah dinilai 0, 1-2kali/minggu dinilai 1,3-4 kali /minggu dinilai 2,5-6 kali/minggu dinilai 3,1 kali/hari dinilai 4,2kali/hari dinilai 5 . sedangkan total jumlah dari pertanyaan disimpulkan bahwa 0-5 dinilai rendah, 6-8 dinilai sedang,9-25 dinilai tinggi. dari nilai JFIM sudah dapat mewakili frekuensi konsumsi junk food yang dikonsumsi (Boylan et al, 2017).

\section{HASIL}

Hasil penelitian digambarkan tentang data umum dan data khusus penelitian. Data umum meliputi usia, pendidikan orang tua, pekerjaan orang tua, IMT. Data khusus adalah frekuensi konsumsi junk food yang sesuai dengan questionare JFIM.

Tabel 1. Karakteristik Responden dan Variabel

\begin{tabular}{cccc}
\hline No & Variabel & Jumlah & $\%$ \\
\hline 1. & Usia & & \\
\hline & 12 & 18 & 10,8 \\
& 13 & 66 & 39,8 \\
& 14 & 48 & 28,9 \\
& 15 & 29 & 17,5 \\
& 16 & 5 & 3,0 \\
& Total & 166 & 100 \\
\hline
\end{tabular}

\begin{tabular}{|c|c|c|c|}
\hline 2 & $\begin{array}{c}\text { Pendidikan Orang } \\
\text { Tua }\end{array}$ & & \\
\hline & SD & 17 & 10,2 \\
\hline & SMP & 22 & 13,3 \\
\hline & SMA & 95 & 57,2 \\
\hline & PT & 32 & 19,3 \\
\hline & Total & 166 & 100 \\
\hline 3 & $\begin{array}{l}\text { Pekerjaan Orang } \\
\text { Tua }\end{array}$ & & \\
\hline & PNS & 50 & 30,1 \\
\hline & Swasta & 53 & 31,9 \\
\hline & Wiraswasta & 43 & 25,9 \\
\hline & Lain-lain & 20 & 12,0 \\
\hline & Total & 166 & 100 \\
\hline 4 & IMT/ Index Masa & & \\
\hline & Tubuh & & \\
\hline & Kurus & 0 & 0 \\
\hline & Normal & 0 & 0 \\
\hline & Overweight/Gemuk & 6 & 3,6 \\
\hline & Obese & 5 & 3 \\
\hline & Obese Level 1 & 98 & 59,0 \\
\hline & Obese Level 2 & 57 & 34,3 \\
\hline & Total & 166 & 100 \\
\hline 5 & Skor JIFM & & \\
\hline & Rendah (0-5) & 4 & 2,4 \\
\hline & Sedang (6-8) & 22 & 13,3 \\
\hline & Tinggi (9-25) & 140 & 84,3 \\
\hline & Total & 166 & 100 \\
\hline
\end{tabular}

Berdasarkan tabel 1 didapatkan data bahwa responden umur 12 tahun sebanyak $(10.8 \%)$ dan terbanyak usia 13 tahun $(39,75 \%)$, usia 14 tahun sebanyak $(28,9 \%)$, Usia 15 tahun sebanyak (17,5\%), Usia 16 tahun sebanyak (3\%). Karakteristik responden berdasarkan tingkat pendidikan orang Tua dari PT sebanyak 32 anak $(19,3 \%)$, SMA sebanyak 95 orang $(57,2 \%)$, SMP sebanyak 22 orang $(13,3 \%)$, dan SD sebanyak 17 orang $(10,2 \%)$. Pekerjaan orang Tua di SMPN 27 terdapat PNS sebanyak $50(30,1 \%)$ orang, Swasta 53 orang $(31,9 \%)$, Wiraswasta sebanyak 43 orang $(25,9 \%)$, dan lain-lain sebanyak20 orang $(12,0 \%)$. Status Gizi atau IMT pada Siswa dan Siswi di SMPN 27 Surabaya yang terbanyak adalah overweight atau gemuk sebaanyak 6 orang $(3,6 \%)$, obese sebaanyak 5 orang $(3,0 \%)$, dan Obese level 1 sebanyak 98 orang $(59,0 \%)$, dan obese level 2 sebanyak 57 orang (34,3\%).Skoring JFIM pada Siswa dan Siswi di SMPN 27 Surabaya, dengan skoring Rendah (0-5) sebanyak 4 orang $(2,4 \%)$, Sedang $(6-8)$ 
sebanyak 22 orang (13,3\%), dan Tinggi (9$25)$ sebanyak 140 orang $(84,3 \%)$.

Tabel 2. Hubungan Konsumsi Makanan Cepat Saji dengan Kejadian Obesitas

\begin{tabular}{|c|c|c|c|c|c|}
\hline \multirow{2}{*}{$\begin{array}{l}\text { Variabel } \\
\text { JFIM (\%) }\end{array}$} & \multicolumn{5}{|c|}{ Level Obesitas (\%) } \\
\hline & $\begin{array}{c}\text { Over } \\
\text { weig } \\
\text { ht }\end{array}$ & $\begin{array}{l}\text { Obe } \\
\text { sitas } \\
\text { level }\end{array}$ & $\begin{array}{c}\text { Obe } \\
\text { sitas } \\
\text { Leve } \\
\quad 1\end{array}$ & $\begin{array}{l}\text { Obe } \\
\text { sitas } \\
\text { Lev } \\
\text { el } 2 \\
\end{array}$ & Total \\
\hline $\begin{array}{c}\text { Rendah (0- } \\
5)\end{array}$ & 1,2 & 0 & 0,6 & 0,6 & 2,4 \\
\hline $\begin{array}{c}\text { Sedang } \\
(6-8)\end{array}$ & 2,4 & 1,8 & 4,3 & 4,8 & 13,3 \\
\hline $\begin{array}{l}\text { Tinggi } \\
(9-25)\end{array}$ & 0 & 1,2 & 54,2 & 28,9 & 84,3 \\
\hline Total & 3,6 & 3 & 59,1 & 34,3 & 100 \\
\hline
\end{tabular}

Berdasarkan tabel 2 didapatkan bahwa frekuensi konsumsi makanan cepat saji berdampak pada Status Gizi pada Remaja di Surabaya, yaitu sebanyak 2 orang remaja $(1,2 \%)$ yang frekuensi konsumsi makanan cepat saji rendah mempunyai tubuh dengan IMT atau status gizi overweight, sebanyak $0(0 \%)$ orang remaja yang memiliki frekuensi konsumsi junk food rendah mengalami IMT atau status gizi obesitas, sebanyak $1(0,6 \%)$ orang remaja yang memiliki frekuensi konsumsi junk food rendah memiliki IMT atau status gizi obesitas level 1 , dan sebanyak 1 orang $(0,6 \%)$, remaja yang memiliki frekuensi konsumsi junk food rendah juga memiliki IMT atau status Gizi obesitas level 2.Sedangkan remaja yang biasa mengkonsumsi junk food dengan skoring JFIM sedang terdapat 4 orang $(2,4 \%)$ orang dengan Status Gizi atau IMT overweight, 3 orang $(1,8 \%)$ obesitas, $7(4,3 \%)$ orang obesitas level 1 , dan 8 orang $(4,8 \%)$ orang obesitas level 2. Dan Remaja yang mengalami skoring JFIM Tinggi terdapat 0 orang $(0 \%)$ overweight, 2 orang $(1,2 \%)$ obesitas, 92 orang $(55,4 \%)$ obesitas level 1,46 orang $(27,7 \%)$ mengalami Status Gizi yang obesitas level2.

Berdasarkan hasil uji Spherman's Rho menunjukan nilai $r=0,162$ dengan nilai $P=$ 0,037 maka secara statistik menunjukkan adanya hubungan tingkat konsumsi junk food terhadap status Gizi pada remaja di SMPN 27 Surabaya.

\section{PEMBAHASAN}

Berdasarkan penelitian konsumsi makanan cepat saji didapatkan Rendah (0$5)$ sebanyak 4 orang $(2,4 \%)$, Sedang (6-8) sebanyak 22 orang $(13,3 \%)$, dan Tinggi (925) sebanyak 140 orang (84,3\%). Hasil penelitian menunjukkan intake makanan cepat saji pada remaja di Surabaya cukup tinggi. Hal ini dipengaruhi oleh berbagai hal yang tertera pada data demografi yang ada bahwa remaja banyak tinggal di dekat sekolah yang mana pada daerah perkotaan yang masyarakatnya cenderung ingin semua serba cepat dan instan, disisilain kondisi orang tua yang bekerja dua-duanya sehingga kurang dalam menyediakan masakan sehat bagi anak-anak mereka. Status sosial ekonomi yang cukup sehingga membuat para orang Tua lebih memilih hal yang praktis dan mudah untuk membeli makanan cepat saji seperti Junk food.

Hal ini juga didukung dari gerai-gerai industri makanan cepat saji yang mulai bermunculan baik yang dalam skala besar dan kecil seperti gerai-gerai kaki lima yang banyak menjual junk food seperti ayam goreng tepung, kentang, dan banyak lagi makanan ringan serta minuman yang dijual banyak mengandung karbohidrat, gula, garam dan MSG serta pemanis buatan yang kadar gulanya lebih tinggi dari gula biasa. Sedangkan karena prastise, dan ingin serba cepat membuat para orang tua lebih memilih untuk membeli makanan cepat saji ataupun junk food baik itu melalui gerai kaki lima ataupun gerai-gerai yang besar seperti yang sedang bertumbuh dalam industri makanana fast food di kota Surabaya. Hal ini perlu perhatian khusus bagi pemerintah kota Surabaya untuk lebih membatasi berkembangnya industri makanan junk food dan lebih memilih berkembangnya industri makanan tradisional yang sehat. Junk food banyak mengandung tinggi lemak,tinggi gula, tinggi karbohidrat dan sodium sehingga dapat mengakibatkan beberapa dampak 
negatif yang akan muncul yaitu meningkatkan resiko serangan jantung,membuat ketagihan,meningkatkan berat badan,memicu diabetes, memicu tekanan darah tinggi, meningkatkan resiko kanker dan mengakibatkan anemia.

Berdasarkan tabel 2 didapatkan bahwa terdapat hubungan antara konsumsi makanan cepat saji dengan derajat obesitas. Mengkonsumsi makanan cepat saji dalam jumlah banyak dan dalam beberapa minggu akan menyebabkan tubuh mengalami penambahan berat badan yang tidak sehat. Lemak yang di dapat dari mengkonsumsi makanan cepat saji tidak digunakan dengan baik oleh tubuh jika tidak berolahraga. Lemak inilah yang kemudian tersimpan dan menumpuk dalam tubuh.( Virgianto dan Purwaningsih, 2006). Makanan cepat saji atau yang lebih dikenal Junk food mengandung asam jenuh yang tinggi, omega 6 asam lemak, asupan omega 3 lemak yang kurang dan garam serta gula yang berlebihan, sehingga makanan tersebut dapat merusak jantung, ginjal, dan obesitas. Namun semakin jelas terlihat bahwa Junk food juga merusak sisitem kekebalan tubuh (Gopal, 2012).

Junk food (makanan cepat saji) memiliki karakteristik tinggi lemak, tinggi karbohidrat, dan tinggi energi. Junk food dengan kombinasi giizi yang tidak seimbang tersebut apabila jenis makan tersebut menjadi pola makan sehari-hari, maka akan menyebabkan terjadinya kegemukkan (Apriadji, 2008). Hubungan kandunganlemak yang tinggi pada Junk foodtidak terlepas dari sifat lemak sendiri yang dapat menghasilkan 9 energi untuk setiap gramnya, yaitu 2,25 kali lebih besar energi yang dihasilkan oleh karbohidrat dan protein dalam jumlah yang sama (Almatsier, 2009).

Hubungan kandungan karbohidrat yang tinggi pada Junk foodtidak terlepas dari mekanisme karbohidrat didalam tubuh berada dalam sirkulasi darah sebagai glukosa untuk keperluan energi, sebagian disimpan sebagai glikogen dalam hati dan jaringan otot, dan sebagian diubah menjadi lemak untuk kemudian disimpan sebagai cadangan energi (Almatsier, 2009). Hubungan kandungan energi yang tinggi pada Junk foodtidak terlepas dari energi yang berasal dari karbohidrat dan lemak yang keduanya juga memiliki tingkat konsumsi yang hubungannya secara signifikan dengan gizi lebih maupun obesitas. Hal tersebut dikarenakan lemak dan karbohidrat merupakan sumber energi utama dalam tubuh, yaitu dalam 1 gram karbohidrat menghasilkan 4 energi. Oleh karena itu tingginya asupan karbohidrat dan lemak secara tidak langsung akan meningjkatkan asupan energi dalam tubuh sedangkan tubuh memiliki kemampuan yang tidak terhingga dalam menyimpan lemak, sehingga sebanyak apapun lemak yang ada, tubuh akan tetap terus dapat menyimpan lemak. Keadaan tersebut akan menimbulkan gizi lebih maupun obestas yang pada akhirnya akan memunculkan masalah kesehatan lain seperti penyakit degeneratif.

Kandungan gizi yang tidak seimbang ini apabila dikonsumsi berlebih akan menimbulkan masalah gizi, dan merupakan faktor risiko berat badan lebih atau obesitas serta penyakit degenartif seeperti kardiovaskuler, diabetes mellitus, artritits, penyakit kantong empedu, kanker, gangguan fungsi nafas dan berbagai gangguan kulit. Semakin banyak makanan cepat saji yang dikonsumsi, semakin besar pula risiko terjadinya obesitas (Austin, 2005). Penelitian oleh Fauzul (2012) pada siswa sekolah dasar di Manado menyebutkan bahwa siswa - siswi yang sering mengkonsumsi Junk foodminimal 3 kali per minggu mempunyai risiko 3,28 kali menjadi gizi lebih. Hal ini didukung oleh penelitian yang dilaksanakan oleh Virgianto (2005) mengenai konsumsi Junk food sebagai faktor risiko terjadinya obesitas pada remaja usia 15-17 tahun didapatkan hasil, semakin tinggi kontribusi makanan cepat saji pada total energi, semakin tinggi risiko terjadinya obesitas. 


\section{KESIMPULAN}

Hasil penelitian menunjukkan bahwa terdapat hubungan antara konsumsi makanan cepat saji dengan kejadian obesitas pada remaja di Surabaya.

\section{SARAN}

Perlu kerjasama yang baik antara pihak sekolah dan Puskesmas dalam mengedukasi remaja tentang bahaya mengkonsumsi junkfood dalam frekuensi yang tinggi. Selain itu penting juga untuk memberikan edukasi kepada orang tua agar menyediakan makanan yang sehat dirumah. Peran sekolah juga sangat penting dalam menyediakan kantin sehat, sehingga gerakan masyarakat sehat yang dicanangkan pemerintah bisa terdukung dengan baik.

\section{DAFTAR PUSTAKA}

Asmadi. 2012. Konsep Dasar Keperawatan, Jakarta: EGC.

Hidayat. 2008. Pengantar Konsep Dasar Keperawatan, Jakarta: Salemba Medika.

Indrayani dan Asmuji. 2014. Buku Ajar Keperawatan Maternitas, Yogyakarta: Ar-ruzz Media.

Kusmiran. 2011. Kesehatan Reproduksi Remaja dan Wanita, Jakarta: Salemba Medika.

Linda dan Danny. 2006. At a Glance Sistem Reproduksi, Jakarta: Erlangga.

Manuaba IAC, Manuaba IBGF dan Manuaba IBG. 2009. Memahami Kesehatan Reproduksi Wanita. Jakarta: EGC, edisi 2.

Nursalam. 2008. Konsep dan Penerapan Metodelogi Penelitian IImu Keperawatan. Jakarta: Nuha Medika.

Riskesdas. 2013. Riset Kesehatan Dasar (RISKESDAS) 2013. Laporan Nasional
2013. pp. 1-384. Available at: www.depkes.go.id

Sukarni dan Wahyu. 2013.Buku Ajar Keperawatan Maternitas, Yogyakarta: Nuha Medika.

Soetjiningsih dan Ranuh. 2012. Tumbuh Kembang Anak, Jakarta: EGC.

Wulandari, S dan Ungsianik, T. 2013. Status Gizi, Aktifitas Fisik dan Usia Menarche Remaja Putri. Jurnal Keperawatan Indonesia, 16(1), pp. 55-59. Available at: www.journal.ui.ac.id.

Adi, A.C., Nusa, dan Adisti F.A. 2013. Hubungan Faktor Perilaku, Frekuensi Konsumsi Fast Food, Diet dan Genetik Dengan Tingkat Kelebihan Berat Badan. Media Gizi Indonesia, Vol 9 No 1 Januari-Juni 2013: hal 20-27.

Almatsier, S. 2004. Prinsip Dasar IImu Gizi. Jakarta: Gramedia Pustaka Utama

Allo, B., Syam dan Virani. 2013. Hubungan Antara Pengerahuan dan Kebiasaan Konsumsi Fast Food dengan Kejadian Gizi Lebih pada Siswa Sekolah Dasar Negeri 1 Sudirman Makassar. Jurnal Kesehatan Masyarakat Universitas Hasanuddin.

Purwanto dan Nurhadi. 2005. Cultural Studies, Teori dan Praktik. Yogyakarta: Kreasi Wacana.

Purwati, S. 2001. Perencanaan Menu untuk Penderita Kegemukan. Jakarta: Penebar Swadaya.

Proverawati, A dan Erna K.W. 2011. IImu Gizi untuk Keperawatan \& Gizi Kesehatan. Yogyakarta: Nuha Medika.

Pusat Data dan Informasi Kemenkes RI. 2014. Situasi Kesehatan Reproduksi Remaja INFODATIN 2014. Jakarta Selatan: Kemenkes RI. 
Hatta, H. 2019. Hubungan Konsumsi Fast Food dengan Status Gizi Siswa di SMP Negeri 1 Limboto Barat. Jurnal Kesehatan Masyarakat Universitas Gorontalo.

RISKESDA Provinsi Jawa Timur. 2018. Hasil Utama Riskesdas 2018 Provinsi Jawa Timur. Kementerian Kesehatan RI.

Health Organization. 2011. Overweight and Obesity. Avaliable from URLhttp://www.who.int/gho/ncd/risk_fac tors/overweight_obesity/obesity_adoles cents/en/ diakses pada tanggal 14 Desember 2019.

Health Organization. 2014. Junk Food. Avaliable from URLhttp://www.who.int/features/2014/u k-food-drink-marketing/en/ diakses pada tanggal 14 Desember 2019.

Buku Saku Pemantauan Status Gizi 2017 Kementrian Kesehatan RI GERMAS

M,. Marie, Saroja, 2017 Awarness On III Effect Of Junk Food Among Higer Secondary Students Tirunelveli Distric St Ignatius College IRJMSH

Vinay, Gopa,I J Student Prespective On Junk Foods : Survey VIT University, Vellore, India.

S Boylan,L.L. Hardy,B.A Assesing Junk Food Consumption among Australian Children : Trend And Associated Characteristic From a Cross-Sectional Study BMC Publik Health

Elizabeth B. Hurlock Psikologi Perkembangan Suatu Pendekatan Sepanjang Rentang Pendidikan, edisi 5, Tahun 2014. Penerbit Erlanga. 